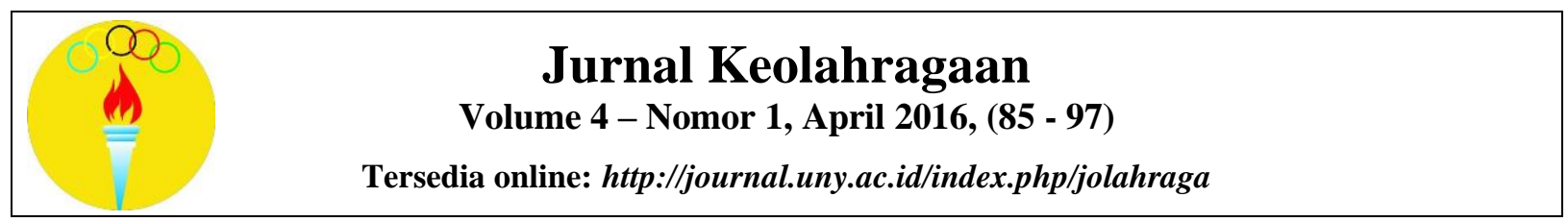

\title{
PENGEMBANGAN TES KEMAMPUAN FISIK BOLABASKET SISWA SMA PUTRA DI PROVINSI DAERAH ISTIMEWA YOGYAKARTA
}

\author{
Taufiq Arif Setyawan $^{1)}$, F.X. Sugiyanto ${ }^{2)}$ \\ ${ }^{1}$ Persatuan Bola Basket Indonesia. Email:taufiqarifsetyawan@gmail.com \\ ${ }^{2}$ Pendidikan Kepelatihan, Fakultas Ilmu Keolahragaan, Universitas Negeri Yogyakarta. Jalan \\ Colombo No 1, Karangmalang Yogyakarta 55281, Indonesia. Email: fx.sugiyanto56@yahoo.co.id
}

\begin{abstract}
Abstrak
Penelitian ini bertujuan untuk mengembangkan tes kemampuan fisik bolabasket yang valid dan reliabel yang dapat digunakan untuk mengukur tingkat kemampuan fisik pemain bolabasket siswa SMA di Daerah Istimewa Yogyakarta (DIY). Subjek penelitian adalah 156 siswa SMA putra di DIY. Produk yang dikembangkan adalah tes kemampuan fisik bolabasket siswa SMA. Langkah pertama sampai keenam merupakan tahap pengembangan standar indikator keterampilan fisik bermain bolabasket siswa SMA. Langkah ketujuh sampai kesepuluh merupakan tahap pengembangan instrumen. Hasil uji skala kecil digunakan sebagai uji coba pengembangan produk dilakukan untuk keperluan pengujian validitas dan reliabilitas instrumen tes. Uji lanjut pada skala besar difokuskan untuk menyusun norma dan standar penilaian atas instrumen tes keterampilan fisik bolabasket. Hasil pengembangan tes keterampilan fisik bermain bolabasket meliputi (1) tes kecepatan 3/4 basketball court sprint, (2) tes daya tahan aerobik bleep test, (3)) tes kelincahan lane agility test, (5) tes daya tahan otot core strange and stability test, (6) tes power tungkai vertical jump, (7) tes power lengan push-up, dan (8) tes fleksibilitas sit and reach. Dapat disimpulkan instrumen tes dapat digunakan sebagai metode evaluasi untuk mengukur kemampuan fisik bolabasket pada anak SMA.
\end{abstract}

Kata Kunci: tes kemampuan fisik, bolabasket, siswa SMA putra

\section{DEVELOPING A TEST OF THE PHYSICAL CAPABILITY FOR BASKETBALL FOR MALE STUDENTS IN THE PROVINCE OF YOGYAKARTA SPECIAL TERRITORY}

\begin{abstract}
This study aims to develop a valid and reliable test of the physical capability for basketball to measure the level of the physical capability for basketball player among senior high school (SHS) students in Yogyakarta Special Territory (YST). The research subjects were 156 male SHS students in the Province of YST. The developed product was a test of the physical capability for basketball for male SHS students. The first to sixth steps belonged to the stage of developing standards for the indicators of the physical skills for playing basketball for SHS students. The seventh to tenth steps belonged to the stage of developing instrumens. The result of the small-scale testing was used as a product development tryout, conducted to test the validity and reliability of the test instrumens. A further test in the large-scale testing was focused on the construction of assessment norms and standards for the test instrumens for the physical skills for basketball. The results of the development of the test of the physical capability for playing basket include (1) a speed test of 3/4 basketball court sprint, (2) an aerobic endurance test of bleep test for basketball, (3) an agility test of lane agility test, (5) a muscle endurance test of core strange and stability test, (6) a heel power test of vertical jump, (7) an arm power test of push-up, and (8) a flexibility test of sit and reach all of these can used as an evaluation method to measure the physical capability for basketball among SHS students.
\end{abstract}

Keywords: test of the physical capability, basketball, male SHS students

How to Cite Item: Setyawan, T., \& Sugiyanto, F. (2016). Pengembangan tes kemampuan fisik bolabasket siswa SMA putra di Provinsi Daerah Istimewa Yogyakarta. Jurnal Keolahragaan, 4(1), 85-97. Retrieved from http://journal.uny.ac.id/index.php/jolahraga/article/view/6415 


\section{PENDAHULUAN}

Permainan bolabasket pada saat ini, apabila dicermati secara teliti mengalami perkembangan yang pesat, baik dari segi fisik, teknik, maupun metode pelatihan. Seperti yang dikemukakan oleh Hoy dan Carter (2007, p.7) bahwa Basketball is a fast-moving, highscoring indoor game that requires of the individual player extreme qualities of skill, precision, control, and agility, as well as the physical prerequisites vital for athletic excellence.

Sesuai dengan pendapat Trninic (2003, p.14) sebagai berikut: The game of basketball is a complex motor multi-structured team activity, based on the symbiosis of cyclic and acyclic movement of individual players with and without the ball, the performance quality of which is directly related to motor-functional conditioning status (fitness) of athletes and their body composition..., basketball is primarily a sport of agility, the latter being a complex combination of several motor abilities.

Kecepatan yang dilakukan pemain mengacu kepada kecepatan reaksi dan berpindah tempat dalam menampilkan keahlian seperti gerakan kaki saat bertahan, merayah (rebound), atau melemparkan bola ketika melakukan tembakan atau operan, bukan hanya sekedar berlari dengan cepat. Pemain harus memiliki kualitas fisik yang prima dan penguasaan teknik permainan yang diharapkan sempurna.

Hal tersebut dapat dijadikan indikasi bahwa teknik bermain bolabasket mengalami perkembangan yang sangat pesat sejalan dengan dampak kemajuan di bidang ilmu pengetahuan dan teknologi. Ilmu olahraga telah berkembang dari bentuk penjelasan yang bersifat alamiah ke bentuk pengetahuan yang lebih pasti, maka menjadi jelas bahwa seorang pelatih memerlukan bantuan keilmuan untuk menjamin programnya agar selalu berada pada dasar penilaian yang objektif. Konsekuensi yang muncul adalah para guru/pelatih bolabasket dituntut untuk selalu dapat mengikuti perkembangan yang terjadi, baik dari segi fisik, teknik, maupun metode berlatih melatih.

Permainan bolabasket saat ini harus ditunjang dengan kemampuan yang sempurna. Pemain yang bagus adalah pemain yang mampu menampilkan performanya yang konsisten dari awal sampai akhir pada setiap babak. Diperlukan kualitas fisik yang bagus melalui latihan dan pembebanan, sehingga akan tercipta kebugaran otot yang akan menunjang setiap komponen biomotor yang ada pada diri atlet. Komponen-komponen biomotor tersebut antara lain: speed, strength, endurance, dan flexibility. Hasil perpaduan antara komponen-komponen biomotor tersebut akan menghasilkan turunan dari komponen biomotor yang lainnya, sebagai contoh hasil perpaduan antara speed dan strength akan menghasilkan power, perpaduan antara strength dengan endurance akan menghasilkan strenght endurance atau stamina.

Menurut pendapat Zhannisa \& Sugiyanto, (2015, p.117), Komponen fisik merupakan pondasi dari prestasi olahraga sebab teknik, taktik dan mental akan dapat dikembangkan dengan baik jika memiliki kualitas fisik yang baik.

Suatu pekerjaan atau disiplin ilmu membutuhkan evaluasi untuk mengetahui sejauh mana pekerjaan yang dilakukan mencapai keberhasilan tertentu. Semua tujuan dan sasaran dapat diketahui keberhasilannya dari apa yang telah dievaluasi dan diukur. Evaluasi, dengan tes sebagai alat ukur dan pengukuran sebagai proses pengambilan data, merupakan suatu pekerjaan yang harus dilakukan untuk mengetahui sejauh mana suatu usaha mencapai hasil yang diharapkan.

Menurut Bompa (1999, p.85) tes adalah instrumen unjuk kerja individu, sedangkan penilaian merupakan proses untuk menentukan status seseorang sesuai kriteria yang dipakai. Fungsi pengukuran adalah untuk mengetahui kemampuan atau keterampilan, menyiapkan dasar untuk mencapai kemajuan, mendiagnosis kelemahan, dan meramalkan kemungkinan di masa depan. Untuk melakukan pengukuran alat yang digunakan harus memenuhi syarat, bahwa instrumen tersebut harus valid, reliabel, relevan, dan objektif, sedangkan pengevaluasian dari data pengukuran bisa menggunakan standar norma atau standar kriteria. Ngatman (2003, p.59) berpendapat bahwa analisis terhadap cabang olahraga ditempuh agar materi tes yang diususun tidak menyimpang dari unsur-unsur penting yang terdapat pada cabang olahraga yang disusun tesnya.

Dalam penelitian ini akan dikembangkan penyusunan tes kemampuan fisik cabang olahraga bolabasket yang terdiri atas tes kecepatan (speed), tes kelincahan (agility), daya tahan kardiorespirasi (endurance), daya tahan anaerobik, daya tahan kekuatan (strength endurance), dan tes power. Sesuai pendapat dari Syafii (2007, p.2) bahwa belum adanya kurikulum baku dan terbatasnya instrumen yang dapat digunakan 
untuk mengukur aspek pembinaan fisik, teknik, taktik, dan mental pemain berdampak pada penerapan model evaluasi yang digunakan pelatih di lapangan. Di tingkat SMA, pengajar maupun pelatih olahraga bolabasket belum menggunakan metode evaluasi secara benar. Unsur subjektivitas masih dipergunakan dalam penilaian dikarenakan beberapa hal yaitu: (1) ketidakpahaman pada konsep evaluasi, (2) terbatasnya perangkat yang bisa dijadikan alat evaluasi, (3) rendahnya budaya untuk melakukan evaluasi. Padahal evaluasi mempunyai fungsi strategis di dalam pengambilan keputusan.

Permasalahan yang terjadi pada tingkat SMA adalah belum ada pengembangan tes kemampuan fisik khusus cabang olahraga bolabasket untuk siswa SMA yang praktis, lebih murah dan mudah digunakan untuk mengetahui kemampuan fisik siswa SMA. Keberadaan instrumen atau alat ukur tes fisik bolabasket untuk tingkat SMA yang pelaksanaannya dilakukan secara objektif sangat dibutuhkan, sehingga evaluasi terhadap perkembangan anak didik tidak semata-mata didasarkan intuisi belaka dan cenderung subjektif.

Peneliti merasa tertarik untuk mengembangkan model tes dan pengukuran kemampuan fisik cabang olahraga bolabasket yang dilaksanakan di lapangan bolabasket, sehingga para pelaku dalam bolabasket tidak akan kesulitan untuk menjalankannya.

\section{METODE}

\section{Jenis Penelitian}

Penelitian yang dilakukan ini menggunakan model penelitian dan pengembangan, bertujuan untuk mengembangkan produk tes kemampuan fisik bolabasket yang semuanya dilakukan di atas lapangan bolabasket dengan harapan agar mempermudah dalam melakukan tes kemampuan fisik cabang olahraga bolabasket di tingkat SMA. Penelitian dengan model pengembangan dipilih karena penelitian pengembangan yang dilakukan ini berorientasi pada produk. Dalam penelitian pengembangan ini peneliti menggunakan analisis kebutuhan atas model tes, pengukuran dan evaluasi berupa sport skill test yang masih jarang ditemukan di lingkungan sekolah. Jadi penelitian pengembangan ini akan menghasilkan sebuah model tes kemampuan fisik bolabasket.

\section{Waktu dan Tempat Penelitian}

Penelitian dan pengembangan ini dilakukan mulai bulan Desember 2012 sampai dengan bulan Maret 2013. Tempat penelitian untuk uji coba yaitu SMA Kollese de Britto, sedangkan untuk uji coba skala besar tempat penelitian tersebar di 13 SMA di Provinsi Daerah Istimewa Yogyakarta yaitu: SMAN 1 Yogyakarta, SMAN 3 Yogyakarta, SMAN 4 Yogyakarta, SMAN 8 Yogyakarta, SMAN 9 Yogyakarta, SMA Bopkri 1 Yogyakarta, SMA Bopkri 2 Yogyakarta, SMA Kollese De Britto, SMAN 1 Kalasan Sleman, SMAN 1 Bantul, SMAN 2 Bantul, SMAN 1 Kulon Progo, SMAN 1 Gunungkidul.

\section{Target/Subjek Penelitian}

Target/subjek penelitian ini untuk uji coba skala kecil adalah 50 siswa SMA Kollese de Britto, sedangkan untuk uji coba skala besar menggunakan 12 orang dari masing-masing SMA sebagai berikut, SMAN 1 Yogyakarta, SMAN 3 Yogyakarta, SMAN 4 Yogyakarta, SMAN 8 Yogyakarta, SMAN 9 Yogyakarta, SMA Bopkri 1 Yogyakarta, SMA Bopkri 2 Yogyakarta, SMA Kollese de Britto, SMAn 1 Kalasan Sleman, SMAN 1 Bantul, SMAN 2 Bantul, SMAN 1 Kulon Progo, SMAN 1 Gunungkidul. Total dari subjek penelitian ini adalah 156 siswa SMA putra yang tersebar di Provinsi Daerah Istimewa Yogyakarta.

\section{Prosedur}

Pengembangan tes kemampuan fisik bolabasket siswa SMA dilakukan dengan menggunakan 10 langkah untuk mengkonstruksinya dari Strand dan Wilson (Morrow, dkk, 2005, p.311). Teknik ini biasa dipakai untuk membangun atau mengembangkan tes psikomotorik. Teknik ini digunakan dengan harapan dapat memperoleh instrumen yang valid dan reliabel dengan melibatkan para ahli dalam bidang olahraga khususnya ahli mengenai permainan bolabasket. Menurut Sugiyono (2011, p.414) validasi desain merupakan proses kegiatan untuk menilai apakah rancangan produk baru secara rasional akan lebih efektif dari yang lama atau tidak. Berikut Langkah pengembangan menurut strand dan wilson (Morrow, dkk, 2005, p.311). 


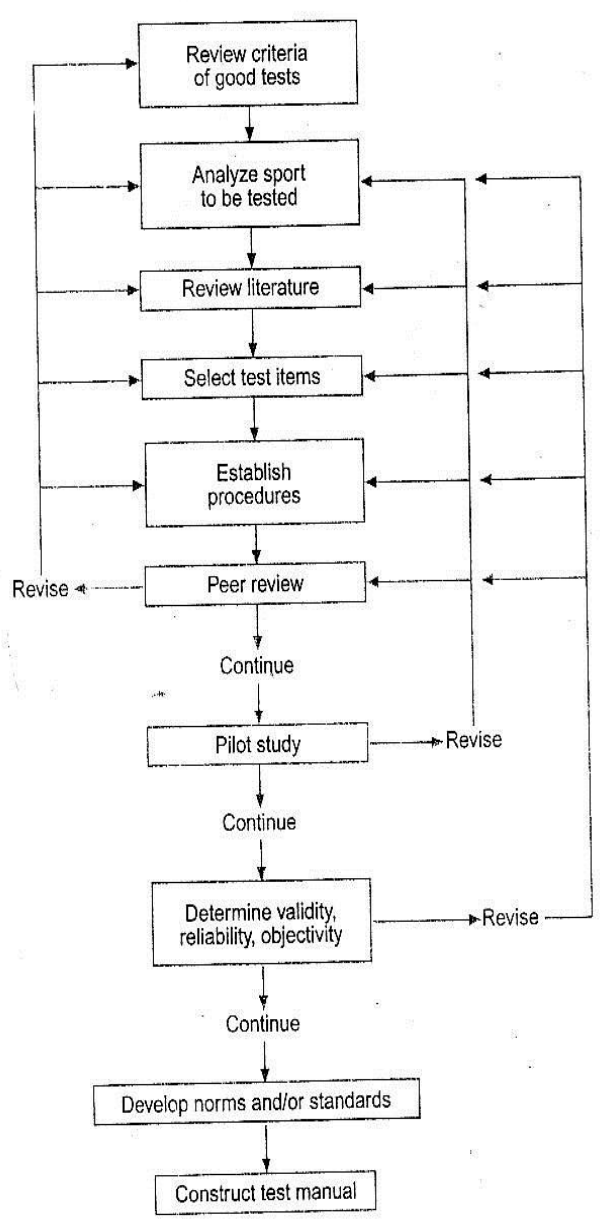

Gambar 1. Bagan Pengembangan Tes Psikomotor Olahraga (Morrow, dkk, (2005, p.311)

Langkah pertama sampai keenam dalam 10 step flowchart dari Strand dan Wilson merupakan tahap pengembangan standar indikator keterampilan fisik bermain bolabasket siswa SMA. Langkah ketujuh sampai kesepuluh merupakan tahap pengembangan instrumen.

Langkah pertama sampai keenam dalam flowchart Strand dan Wilson digunakan untuk mendiskusikan draft naskah awal kualifikasi standar kompetensi permainan bolabasket untuk tingkat SMA dalam rangka merancang dan menyusun indikator keterampilan fisik permainan bolabasket pada tingkat SMA. Langkah keenam yaitu peer review membutuhkan para ahli yaitu para guru atau pelatih yang sudah terbiasa dalam aktivitas cabang olahraga tersebut (Morrow dkk, 2005, p.312).

Langkah pertama adalah membuat review kriteria dari sebuah tes keterampilan fisik bolabasket untuk SMA yang baik. Menurut Budiwanto (2003, p.134) secara umum, kriteria tes yang baik harus memenuhi tingkat validitas dan reliabilitas. Selanjutnya, tes tersebut hendaknya ekonomis, praktis, adanya norma penilaian dan dilengkapi petunjuk pelaksanaan dan cara menskor. Beberapa tes keterampilan yang memenuhi persyaratan seperti langkah pertama adalah: tes kecepatan (sprint) 40 meter, tes daya tahan lari multi tahap (multistage fitness test/ bleep test), tes kelincahan hexagon, dan tes ketahanan otot dengan weight trainning.

Langkah kedua adalah menganalisis keterampilan-keterampilan fisik cabang olahraga yang akan diukur dan akan dijadikan butir tes eksperimen (Morrow dkk, 2005, p.311). Langkah pertama dan langkah kedua sangat terkait dengan langkah ketiga. Langkah ketiga adalah mereview langkah pertama dengan langkah kedua dan membandingkannya dengan pengetahuan yang ada di literatur. Berdasarkan kajian pustaka dan diskusi dengan para ahli bolabasket maka indikator tes keterampilan bolabaket untuk siswa SMA dapat ditentukan. Indikator tes keterampilan fisik tersebut adalah: kecepatan, daya tahan kardiorespirasi, kelincahan, power tungkai, dan daya tahan otot.

Pengembangan tes tersebut adalah sebagai berikut: (1) tes kecepatan 3/4 basketball court sprint, (2) tes kelincahan NCAA test, (3) tes fleksibilitas sit and reach, (4) tes power lengan push-up, (5) tes power tungkai vertical jump, (6) tes daya tahan otot core strange and stability test, dan (7) tes daya tahan aerobik bleep test.

Langkah ketujuh adalah pilot study atau uji coba skala kecil. Indikator tes keterampilan fisik diuji cobakan untuk mendapatkan validitas dan reliabilitas instrumen. Langkah kedelapan mendapatkan validitas dan reliabilitas. Revisi selalu dilakukan untuk menyempurnakan dari draft awal sampai langkah kedelapan. Langkah kesembilan yaitu menentukan norma dan standar tes keterampilan fisik menggunakan uji skala besar yang kemudian berlanjut ke langkah sepuluh yaitu mengkonstruksi tes sehingga didapat produk final.

\section{Data, Instrumen, dan Teknik Pengumpulan Data}

Data yang diperoleh dalam penelitian ini adalah data kuantitatif dari pemberian skor masing-masing indikator dalam tes keterampilan fisik bolabasket yang diujicobakan.

Instrumen yang digunakan untuk pengumpulan data dalam pengembangan instrumen untuk mengukur kemapuan fisik untuk bolabasket siswa SMA ini adalah suatu bentuk 
tes psiko-motor atau suatu battery test keterampilan fisik bolabasket. Instrumen tersebut berupa macam tes keterampilan fisik cabang bolabasket yang sudah melalui peer review.

Teknik pengumpulan data dalam penelitian ini adalah menggunakan tes dan pengukuran psikomotor atau kemampuan fisik cabang olahraga bolabasket yang berupa battery test.

\section{Teknik Analisis Data}

Teknik analisis data dalam penelitian ini menggunakan analisis deskriptif kuantitatif. Analisis deskriptif kuantiatif digunakan untuk mengolah data mentah dari hasil observasi di lapangan. Validitas dalam penelitian ini terdiri atas validitas isi (content validity) dan validitas konstruk (construct validity). Azwar (2006, pp.45-48) menyatakan bahwa pertanyaan yang dicari jawabannya dalam validitas ini adalah sejauh mana butir-butir tes mencakup keseluruhan kawasan isi objek yang hendak diukur atau sejauh mana isi tes mencerminkan ciri atribut yang hendak diukur. Reliabilitas dalam penelitian ini menggunakan metode test-retest, selanjutnya koefisien reliabilitasdihitung menggunakan alpha cronbach's. Uji coba skala kecil dalam penelitian ini digunakan untuk menentukan validitas dan reliabilitas. Setelah diperoleh validitas dan reliabilitas, langkah selanjutnya menentukan norma dengan uji coba skala besar. Oleh karena data diukur menggunakan battery test, maka data diubah dalam bentuk $z$ score dengan rumus sebagai berikut:

$$
\text { Z Score }=\frac{x-\bar{x}}{\text { St.dev }}
$$

Untuk menyamakan satuan, maka data harus diubah dalam bentuk $T$ score dengan rumus sebagai berikut:

$$
\mathrm{T} \text { Score }=50+10 *\left(\frac{x-\bar{x}}{S D}\right)
$$

Nilai $T$ score pada masing-masing komponen keterampilan fiik selanjutnya dijumlahkan sehingga memperoleh skor keterampilan fisik secara keseluruhan.

\section{HASIL DAN PEMBAHASAN}

Prosedur pengembangan tes keterampilan bermain bolabasket siswa SMA dibagi menjadi dua tahap, yaitu tahap pengembangan standar indikator kemampuan fisik bolabasket siswa SMA dan tahap pengembangan instrumen.
Langkah pertama sampai keenam dalam 10 step flowchart dari Strand dan Wilson merupakan tahap pengembangan standar indikator keterampilan fisik bermain bolabasket siswa SMA. Langkah ketujuh sampai kesepuluh merupakan tahap pengembangan instrumen.

Langkah pertama sampai keenam dalam flowchart Strand dan Wilson (Morrow, dkk, 2005: 311) digunakan untuk mendiskusikan draft naskah awal kualifikasi standar kompetensi permainan bolabasket untuk tingkat SMA dalam rangka merancang dan menyusun indikator keterampilan fisik permainan bolabasket pada tingkat SMA. Langkah keenam yaitu peer review membutuhkan para ahli yaitu para guru atau pelatih yang sudah terbiasa dalam aktivitas cabang olahraga tersebut.

Membuat review kriteria dari sebuah tes keterampilan fisik bolabasket untuk SMA yang baik

Peneliti melakukan review terhadap berbagai tes keterampilan fisik bolabasket. Pertimbangan review yaitu dengan melihat tingkat validitas dan reliabilitas instrumen tes. Pertimbangan selanjutnya dalam memilih instrumen yaitu tes harus ekonomis, praktis, adanya norma penilaian dan dilengkapi petunjuk pelaksanaan dan cara mensekor.

Hasil review diperoleh beberapa tes keterampilan yang memenuhi persyaratan seperti langkah pertama adalah: tes kecepatan (sprint) 40 meter, tes daya tahan lari multi tahap (multistage fitness test/bleep test), tes kelincahan hexagon dan tes ketahanan otot dengan weight trainning.

Menganalisis keterampilan-keterampilan fisik cabang olahraga yang akan diukur

Peneliti melakukan analisis terhadap keterampilan-keterampilan fisik cabang olahraga yang akan diukur dan akan dijadikan butir tes eksperimen. Keterampilan fisik yang diukur harus mencakup seluruh kemampuan fisik bolabasket siswa. Keterampilan fisik tersebut meliputi kecepatan, kelincahan, fleksibilitas, power lengan, power tungkai, daya tahan kekuatan, daya tahan aerobik dan daya tahan anaerobik.

\section{Melakukan Kajian Literatur}

Peneliti melakukan kajian literatur baik dari buku, jurnal nasional maupun internasional sebagai dasar untuk menentukan jenis tes keterampilan fisik bolabasket. Hasil pengkajian yang telah peneliti lakukan selanjutnya diban- 
dingkan dengan pengetahuan yang ada di literatur. Berdasarkan Bab II Kajian Pustaka dan diskusi dengan para ahli bolabasket maka indikator tes keterampilan bolabaket untuk siswa SMA dapat ditentukan. Indikator tes keterampilan fisik tersebut meliputi kecepatan, kelincahan, fleksibilitas, power lengan, power tungkai, daya tahan kekuatan, dan daya tahan aerobik.

\section{Memilih Jenis Tes}

Inti dari penelitian ini adalah memodifikasi dan menyesuaikan instrumen tes dan pengukuran dengan keterbatasan sarana dan prasarana yang ada di lapangan bolabasket. Terdapat serangkaian tes yang terdiri atas 7 macam tes yang sudah dimodifikasi dan disesuaikan dengan kebutuhan cabang olahraga bolabasket yang mendasar.

Tabel 1. Metode Umum Tes Fisik dan Modifikasinya.

\begin{tabular}{|c|c|c|c|}
\hline No & $\begin{array}{c}\text { Metode } \\
\text { umum }\end{array}$ & Sasaran & Modifikasi \\
\hline 1 & $\begin{array}{l}\text { sprint } 20 \\
\text { dan atau } 40 \\
\text { meter }\end{array}$ & kecepatan & $\begin{array}{l}\text { Sprint } 3 / 4 \text { court } \\
(22,2 \mathrm{~m})\end{array}$ \\
\hline 2 & $\begin{array}{l}\text { Hexagon } \\
\text { test }\end{array}$ & kelincahan & Lane agility test \\
\hline 3 & $\begin{array}{l}\text { Sit and } \\
\text { reach test }\end{array}$ & fleksibilitas & $\begin{array}{l}\text { Sit and reach } \\
\text { test dengan } \\
\text { bangku dan } \\
\text { penggaris mika }\end{array}$ \\
\hline 4 & Bench press & $\begin{array}{l}\text { power } \\
\text { lengan }\end{array}$ & Push-up \\
\hline 5 & $\begin{array}{l}\text { Vertical } \\
\text { jump dan } \\
\text { Squad pada } \\
\text { Gym }\end{array}$ & $\begin{array}{l}\text { power } \\
\text { tungkai }\end{array}$ & Vertical jump \\
\hline 6 & $\begin{array}{l}\text { Standart } \\
\text { strength test }\end{array}$ & $\begin{array}{c}\text { daya tahan } \\
\text { kekuatan }\end{array}$ & Core test \\
\hline 7 & $\begin{array}{l}\text { Cooper test } \\
\text { dan Multi } \\
\text { stages } \\
\text { fitness test }\end{array}$ & $\begin{array}{c}\text { daya tahan } \\
\text { aerobik }\end{array}$ & $\begin{array}{l}\text { Bleep test for } \\
\text { basketball }\end{array}$ \\
\hline
\end{tabular}

\section{Pengujian Validitas dan Reliabilitas pada Skala Kecil}

Pengujian validitas instrumen tes menggunakan uji test-retest yaitu data hasil dua kali pengamatan menggunakan instrumen yang sama. Hasil pengujian validitas instrumen tes keterampilan fisik bola basket yang meliputi kecepatan, kelincahan, fleksibilitas, power lengan, power tungkai, daya tahan kekuatan, dan daya tahan aerobik dapat dilihat pada tabel berikut.
Tabel 2. Hasil Uji Validitas Instrumen

\begin{tabular}{cccc}
\hline Instrumen tes & r hitung & r tabel & Keterangan \\
\hline Speed & 0,943 & 0,279 & Valid \\
Agility & 0,947 & 0,279 & Valid \\
Sit and reach & 0,990 & 0,279 & Valid \\
Push up & 0,965 & 0,279 & Valid \\
Vertical jump & 0,978 & 0,279 & Valid \\
Core test & 0,922 & 0,279 & Valid \\
Bleep test & 0,928 & 0,279 & Valid \\
\hline
\end{tabular}

Hasil pengujian hipotesis penelitian tersebut dibandingkan dengan nilai $r$ tabel. Nilai $\mathrm{r}$ tabel $\mathrm{N}=50$ taraf signifikansi 5\% sebesar 0,279 . Berdasarkan hasil tersebut diketahui bahwa hasil uji validitas pada seluruh instrumen menunjukkan nilai $r$ hitung $>r$ tabel. Hasil ini dapat diartikan bahwa seluruh instrumen tes yang disusun dalam tes keterampilan fisik bola basket yang meliputi kecepatan, kelincahan, fleksibilitas, power lengan, power tungkai, daya tahan kekuatan, dan daya tahan aerobik dinyatakan valid.

Tabel 3. Hasil Uji Reliabilitas

\begin{tabular}{ccc}
\hline Variabel & $\begin{array}{c}\text { Koefisien } \\
\text { Alpha Cronbach }\end{array}$ & Keterangan \\
\hline Speed & 0,969 & Reliabel \\
Agility & 0,973 & Reliabel \\
Sit and reach & 0,995 & Reliabel \\
Push up & 0,982 & Reliabel \\
Vertical jump & 0,989 & Reliabel \\
Core test & 0,960 & Reliabel \\
Bleep test & 0,962 & Reliabel \\
\hline
\end{tabular}

Hasil pengujian reliabilitas pada seluruh instrumen tes keterampilan fisik bola basket yang meliputi kecepatan, kelincahan, fleksibilitas, power lengan, power tungkai, daya tahan kekuatan, dan daya tahan aerobik menunjukkan nilai koefisien reliabilitas $>0,6$. Hasil ini dapat disimpulkan bahwa seluruh instrumen tes keterampilan fisik bola basket adalah reliabel dan layak dilanjutkan untuk digunakan dalam pengambilan data penelitian skala besar.

\section{Membuat Norma dan Standar Penilaian}

Setelah hasil pengujian skala kecil diperoleh hasil yang menyatakan seluruh instrumen tes keterampilan fisik bolabasket valid dan reliabel maka tahap selanjutnya adalah pengambilan data dalam skala besar. Uji skala besar dilakukan pada siswa SMA pada setiap tim atau ekstra kurikuler bolabasket di Provinsi DIY. Pengambilan data uji skala besar dilakukan menggunakan instrumen tes keterampilan fisik bolabasket yang sudah dinyatakan valid dan reliabel. 


\section{Jurnal Keolahragaan 4 (1), April 2016 - 91}

Taufiq Arif Setyawan, F.X. Sugiyanto

Hasil pengambilan data dalam uji skala besar digunakan sebagai dasar untuk membuat norma dan standar penilaian terhadap keterampilan fisik bolabasket. Penyusunan norma dan standar penilaian didasarkan pada Patokan Acuan Norma yang didasarkan pada nilai mean dan standar deviasi hitung. Formulasi rumus perhitungan norma dan standar yang digunakan adalah sebagai berikut:

$$
\begin{array}{ll}
\text { Sangat baik } & : X \geq M+1,5 \mathrm{SD} \\
\text { Baik } & : M \leq X<M+1,5 \mathrm{SD} \\
\text { Cukup } & : M-1,5 \mathrm{SD} \leq \mathrm{X}<\mathrm{M} \\
\text { Kurang } & : \mathrm{M}-1,5 \mathrm{SD} \geq \mathrm{X}
\end{array}
$$

Hasil data uji skala besar serta perhitungan norma dan standar penilaian tes keterampilan fisik bolabasket adalah sebagai berikut.

\section{Tes kecepatan (sprint)}

Hasil pengujian analisis deskriptif hasil tes kecepatan menggunakan sprint adalah sebagai berikut.

Tabel 4. Hasil Analisis Deskriptif Data Speed

\begin{tabular}{cccccc}
\hline \multicolumn{6}{c}{ Data Kecepatan } \\
\hline Min & Max & Mean & Median & Modus & Std. Dev \\
\hline 2,86 & 5,21 & 3,86 & 3,89 & 3,21 & 0,48 \\
\hline
\end{tabular}

Hasil analisis data speed diperoleh skor terendah adalah 2,86 dan skor tertinggi adalah 5,21 . Hasil analisis statistik deskriptif diperoleh rerata $(\mathrm{M})=3,86$; Simpangan Baku $(\mathrm{SB})=$ 0,$48 ;$ Median $(\mathrm{Me})=3,89 ;$ dan Modus $(\mathrm{Mo})=$ 3,21 .

Berdasarkan hasil analisis deskriptif tersebut diketahui nilai rerata 3,86 dan nilai standar deviasi sebesar 0,48 yang selanjutnya digunakan sebagai dasar penyusunan norma dan standar tes speed. Perhitungan norma tes speed adalah sebaai berikut.

$\begin{array}{ll}\text { Mean } & 3.86 \\ \text { St. Dev } & 0.48 \\ \mathrm{Mi}+1.5 \mathrm{SDi} & 4.58 \\ \mathrm{Mi} & 3.86 \\ \mathrm{Mi}-1.5 \mathrm{SDi} & 3.14\end{array}$

Selanjutnya dimasukkan dalam formulasi rumus berikut.

$$
\begin{array}{ll}
\text { Sangat baik } & : X \geq M+1,5 \mathrm{SD} \\
\text { Baik } & : M \leq X<M+1,5 \mathrm{SD} \\
\text { Cukup } & : M-1,5 \mathrm{SD} \leq \mathrm{X}<\mathrm{M} \\
\text { Kurang } & : \mathrm{M}-1,5 \mathrm{SD} \geq \mathrm{X}
\end{array}
$$

\begin{tabular}{|c|c|c|c|c|c|}
\hline Kategori & \multicolumn{5}{|c|}{ Skor } \\
\hline Sangat baik & $X$ & $\geq$ & 4.58 & & \\
\hline Baik & 3.86 & $\leq$ & $X$ & $<$ & 4.58 \\
\hline Cukup & 3.14 & $\leq$ & $\mathrm{X}$ & $<$ & 3.86 \\
\hline Kurang & $X$ & $\leq$ & 3.14 & & \\
\hline
\end{tabular}

Diperoleh hasil perhitungan norma dan standar tes keterampilan fisik bolabasket pada tes kecepatan sebagai berikut.
Kecepatan termasuk data inversi, semakin cepat waktu pelaksanaan semakin baik, maka norma dan standard penilaian kecepatan pada tes keterampilan fisik bolabasket tingkat SMA adalah sebagai berikut.

Tabel 5. Norma dan Standar Penilaian Kecepatan pada Tes Keterampilan Fisik Bolabasket Tingkat SMA

\begin{tabular}{cc}
\hline Interval Skor & Kategori \\
\hline$x \geq 4,58$ & Kurang \\
$3,86 \leq$ s.d $<4,58$ & Cukup \\
$3,14 \leq \mathrm{s.d}<3,86$ & Baik \\
$x<3,14$ & Sangat Baik \\
\hline
\end{tabular}

\section{Tes Kelincahan (Lane Agility Test)}

Hasil pengujian analisis deskriptif hasil tes kelincahan menggunakan lane agility test adalah sebagai berikut.

Tabel 6. Hasil Analisis Deskriptif Data Kelincahan (Lane Agility Test)

\begin{tabular}{cccccc}
\hline \multicolumn{7}{c}{ Data Lane agility test } \\
\hline Min & Max & Mean & Median & Modus & Std. Dev \\
\hline 11,82 & 15,59 & 13,69 & 13,52 & 13,28 & 0,78 \\
\hline
\end{tabular}

Hasil analisis data lane agility test diperoleh skor terendah adalah 11,82 dan skor tertinggi adalah 15,59. Hasil analisis statistik deskriptif diperoleh rerata $(M)=13,69$; Simpangan Baku $(\mathrm{SB})=0,78$; Median $(\mathrm{Me})=13,52$; dan Modus (Mo) $=13,28$.

Berdasarkan hasil analisis deskriptif tersebut diketahui nilai rerata 13,69 dan nilai standar deviasi sebesar 0,78 yang selanjutnya digunakan sebagai dasar penyusunan norma dan standar lane agility test. Perhitungan norma lane agility test adalah sebagai berikut.

$\begin{array}{lr}\text { Mean } & 13.69 \\ \text { St. Dev } & 0.78 \\ \mathrm{Mi}+1.5 \mathrm{SDi} & 14.86 \\ \mathrm{Mi} & 13.69 \\ \mathrm{Mi}-1.5 \mathrm{SDi} & 12.52\end{array}$

Selanjutnya dimasukkan dalam formulasi rumus berikut.

$\begin{array}{ll}\text { Sangat baik } & : X \geq M+1,5 \mathrm{SD} \\ \text { Baik } & : M \leq X<M+1,5 \mathrm{SD} \\ \text { Cukup } & : M-1,5 \mathrm{SD} \leq \mathrm{X}<\mathrm{M} \\ \text { Kurang } & : \mathrm{M}-1,5 \mathrm{SD} \geq \mathrm{X}\end{array}$


Diperoleh hasil perhitungan norma dan standar tes keterampilan fisik bolabasket pada kelincahan menggunakan lane agility test sebagai berikut.

\begin{tabular}{llrl} 
Kategori & \multicolumn{9}{c}{ Skor } \\
Sangat baik & $:$ & $X$ & $\geq 14.86$ \\
Baik & $:$ & 13.69 & $\leq x$ \\
Cukup & $:$ & 12.52 & $\leq x$ \\
Kurang & $:$ & $X$ & $\leq 12.52$
\end{tabular}

Data tes kelincahan merupakan inversi, semakin cepat waktu pelaksanaannya maka semakin baik sehingga norma dan standar penilaian kelincahan menggunakan lane agility test pada tes keterampilan fisik bolabasket tingkat SMA adalah sebagai berikut.

Tabel 7. Norma dan Standar Penilaian Kelincahan Menggunakan Lane Agility Test pada Tes Keterampilan Fisik Bolabasket Tingkat SMA

\begin{tabular}{cc}
\hline Interval Skor & Kategori \\
\hline$x \geq 14,86$ & Kurang \\
$13,69 \leq$ s.d $<14,86$ & Cukup \\
$12,52 \leq$ s.d $<13,69$ & Baik \\
$x<12,52$ & Sangat baik \\
\hline
\end{tabular}

Tes Fleksibilitas (Sit and Reach Test)

Hasil pengujian analisis deskriptif hasil tes fleksibilitas menggunakan Sit and reach test adalah sebagai berikut.

Tabel 8. Hasil Analisis Deskriptif Data fleksibilitas (Sit and reach test)

\begin{tabular}{cccccc}
\hline \multicolumn{6}{c}{ Data Sit and reach } \\
\hline Min & Max & Mean & Median & Modus & Std. Dev \\
\hline 3,60 & 28,00 & 18,37 & 19,20 & 19,20 & 4,90 \\
\hline
\end{tabular}

Hasil analisis data Sit and reach test diperoleh skor terendah adalah 3,60 dan skor tertinggi adalah 28,00. Hasil analisis statistik deskriptif diperoleh rerata $(\mathrm{M})=18,37$; Simpangan $\mathrm{Baku}(\mathrm{SB})=4,90 ; \operatorname{Median}(\mathrm{Me})=$ 19,20; dan Modus (Mo) = 19,20.

Berdasarkan hasil analisis deskriptif tersebut diketahui nilai rerata 18,37 dan nilai standar deviasi sebesar 4,90 yang selanjutnya digunakan sebagai dasar penyusunan norma dan standar Sit and reach test. Perhitungan norma Sit and reach test adalah sebagai berikut.

$\begin{array}{lr}\text { Mean } & 18.37 \\ \text { St. Dev } & 4.90 \\ \mathrm{Mi}+1.5 \mathrm{SDi} & 25.72 \\ \mathrm{Mi} & 18.37 \\ \mathrm{Mi}-1.5 \mathrm{SDi} & 11.02\end{array}$

Selanjutnya dimasukkan dalam formulasi rumus berikut.

$$
\begin{array}{ll}
\text { Sangat baik } & : X \geq M+1,5 \mathrm{SD} \\
\text { Baik } & : M \leq X<M+1,5 \mathrm{SD} \\
\text { Cukup } & : M-1,5 \mathrm{SD} \leq \mathrm{X}<\mathrm{M} \\
\text { Kurang } & : \mathrm{M}-1,5 \mathrm{SD} \geq \mathrm{X}
\end{array}
$$

Diperoleh hasil perhitungan norma dan standar tes keterampilan fisik bolabasket pada fleksibilitas menggunakan sit and reach test sebagai berikut.

\begin{tabular}{llrlrl}
\multicolumn{1}{c}{ Kategori } & & \multicolumn{5}{c}{ Skor } \\
Sangat baik & $:$ & $\mathrm{X}$ & $\geq 25.72$ & \\
Baik & $:$ & 18.37 & $\leq \mathrm{X}$ & $<25.72$ \\
Cukup & $:$ & 11.02 & $\leq \mathrm{X}$ & $<18.37$ \\
Kurang & $:$ & $\mathrm{X}$ & $\leq 11.02$
\end{tabular}

Maka norma dan standar penilaian fleksibilitas menggunakan sit and reach test pada tes keterampilan fisik bolabasket tingkat SMA adalah sebagai berikut.

Tabel 9. Norma dan Standar Penilaian

\begin{tabular}{|c|c|}
\hline Interval Skor & Kategori \\
\hline$x \geq 25.75$ & Sangat baik \\
\hline $18.37 \leq$ s.d $<25.72$ & Baik \\
\hline $11.02 \leq \mathrm{s} . \mathrm{d}<18.37$ & Cukup \\
\hline$x<11.02$ & Kurang \\
\hline
\end{tabular}
Fleksibilitas Menggunakan Sit and reach pada Tes Keterampilan Fisik Bolabasket Tingkat SMA

Tes Power Lengan (Push-up)

Hasil pengujian analisis deskriptif hasil tes power lengan menggunakan push-up adalah sebagai berikut.

Tabel 10. Hasil Analisis Deskriptif Data Power Lengan (Push Up)

\begin{tabular}{cccccc}
\hline \multicolumn{7}{c}{ Data Push Up } \\
\hline Min & Max & Mean & Median & Modus & Std. Dev \\
\hline 14,00 & 34,00 & 25,09 & 25,00 & 28,00 & 3,98 \\
\hline
\end{tabular}

Hasil analisis data push-up diperoleh skor terendah adalah 14,00 dan skor tertinggi adalah 34,00. Hasil analisis statistik deskriptif diperoleh rerata $(\mathrm{M})=25,09$; Simpangan Baku $(\mathrm{SB})$ $=3,98 ;$ Median $(\mathrm{Me})=25,00 ;$ dan Modus $(\mathrm{Mo})$ $=28,00$.

Berdasarkan hasil analisis deskriptif tersebut diketahui nilai rerata 25,09 dan nilai standar deviasi sebesar 3,98 yang selanjutnya digunakan sebagai dasar penyusunan norma dan standar push-up. Perhitungan norma push up adalah sebagai berikut. 


$\begin{array}{lr}\text { Mean } & 25.09 \\ \text { St. Dev } & 3.99 \\ \mathrm{Mi}+1.5 \mathrm{SDi} & 31.08 \\ \mathrm{Mi} & 25.09 \\ \mathrm{Mi}-1.5 \mathrm{SDi} & 19.11\end{array}$

Selanjutnya dimasukkan dalam formulasi rumus berikut.

$\begin{array}{ll}\text { Sangat baik } & : X \geq M+1,5 \mathrm{SD} \\ \text { Baik } & : \mathrm{M} \leq \mathrm{X}<\mathrm{M}+1,5 \mathrm{SD} \\ \text { Cukup } & : \mathrm{M}-1,5 \mathrm{SD} \leq \mathrm{X}<\mathrm{M} \\ \text { Kurang } & : \mathrm{M}-1,5 \mathrm{SD} \geq \mathrm{X}\end{array}$

Diperoleh hasil perhitungan norma dan standar tes keterampilan fisik bolabasket pada power lengan menggunakan push-up sebagai berikut.

\begin{tabular}{llrl}
\multicolumn{1}{c}{ Kategori } & & \multicolumn{3}{c}{ Skor } \\
Sangat baik & $:$ & $X$ & $\geq 31.08$ \\
Baik & $:$ & 25.09 & $\leq X$ \\
Cukup & $:$ & 19.11 & $\leq X$ \\
Kurang & $:$ & $X$ & $\leq 19.11$
\end{tabular}

Maka norma dan standar penilaian power lengan menggunakan push-up pada tes keterampilan fisik bolabasket tingkat SMA adalah sebagai berikut.

Tabel 11. Norma dan Standar Penilaian Power Lengan (Push-up)

\begin{tabular}{cc}
\hline Interval Skor & Kategori \\
\hline$x \geq 31,08$ & Sangat baik \\
25,09 & $\leq \mathrm{s.d}<31,08$ \\
$19,11 \leq \mathrm{s} . \mathrm{d}<25,09$ & Baik \\
$x<19,11$ & Cukup \\
\hline
\end{tabular}

Tes Power Tungkai (Vertical Jump)

Hasil pengujian analisis deskriptif hasil tes power tungkai menggunakan vertical jump adalah sebagai berikut.

Tabel 12. Hasil Analisis Deskriptif Data Power Tungkai (Vertical Jump)

\begin{tabular}{cccccc}
\hline \multicolumn{6}{c}{ Data Vertical jump } \\
\hline Min & Max & Mean & Median & Modus & Std. Dev \\
\hline 31,00 & 81,00 & 53,78 & 52,00 & 52,00 & 8,28 \\
\hline
\end{tabular}

Hasil analisis data vertical jump diperoleh skor terendah adalah 31,00 dan skor tertinggi adalah 81,00. Hasil analisis statistik deskriptif diperoleh rerata $(M)=53,78$; Simpangan Baku $(\mathrm{SB})=8,28$; Median $(\mathrm{Me})=52,00$; dan Modus (Mo) $=52,00$.

Berdasarkan hasil analisis deskriptif tersebut diketahui nilai rerata 53,78 dan nilai standar deviasi sebesar 8,38 yang selanjutnya digunakan sebagai dasar penyusunan norma dan standar vertical jump. Perhitungan norma vertical jump adalah sebagai berikut.

$\begin{array}{lr}\text { Mean } & 53.78 \\ \text { St. Dev } & 8.28 \\ \mathrm{Mi}+1.5 \mathrm{SDi} & 66.20 \\ \mathrm{Mi} & 53.78 \\ \mathrm{Mi}-1.5 \mathrm{SDi} & 41.36\end{array}$

Selanjutnya dimasukkan dalam formulasi rumus berikut.

$$
\begin{array}{ll}
\text { Sangat baik } & : \mathrm{X} \geq \mathrm{M}+1,5 \mathrm{SD} \\
\text { Baik } & : \mathrm{M} \leq \mathrm{X}<\mathrm{M}+1,5 \mathrm{SD} \\
\text { Cukup } & : \mathrm{M}-1,5 \mathrm{SD} \leq \mathrm{X}<\mathrm{M} \\
\text { Kurang } & : \mathrm{M}-1,5 \mathrm{SD} \geq \mathrm{X}
\end{array}
$$

Diperoleh hasil perhitungan norma dan standar tes keterampilan fisik bolabasket pada power tungkai menggunakan vertical jump sebagai berikut.

\begin{tabular}{llrl}
\multicolumn{1}{c}{ Kategori } & & \multicolumn{3}{c}{ Skor } \\
Sangat baik & $:$ & $X$ & $\geq 66.20$ \\
Baik & $:$ & 53.78 & $\leq X$ \\
Cukup & $:$ & 41.36 & $\leq X$ \\
Kurang & $:$ & $X$ & $\leq 41.36$
\end{tabular}

Maka norma dan standar penilaian power tungkai menggunakan vertical jump pada tes keterampilan fisik bolabasket tingkat SMA adalah sebagai berikut.

Tabel 13. Norma dan Standar Penilaian Power Tungkai Menggunakan Vertical jump pada Tes Keterampilan Fisik Bolabasket Tingkat SMA

\begin{tabular}{cl}
\hline Interval Skor & \multicolumn{1}{c}{ Kategori } \\
\hline$x \geq 66,20$ & Sangat baik \\
$53,78 \leq \mathrm{s.d}<66,20$ & Baik \\
$41,36 \leq \mathrm{s.d}<53,78$ & Cukup \\
$x<41,36$ & Kurang \\
\hline
\end{tabular}

\section{Tes Daya Tahan Kekuatan (Core Test)}

Hasil pengujian analisis deskriptif hasil tes daya tahan kekuatan menggunakan core test adalah sebagai berikut.

Tabel 14. Hasil Analisis Deskriptif Data Daya Tahan Kekuatan (Core test)

\begin{tabular}{cccccc}
\hline \multicolumn{7}{c}{ Data Core test } \\
\hline Min & Max & Mean & Median & Modus & Std. Dev \\
\hline 3,00 & 12,00 & 7,44 & 7,00 & 6,00 & 2,08 \\
\hline
\end{tabular}

Hasil analisis data core test diperoleh skor terendah adalah 3,00 dan skor tertinggi adalah 12,00. Hasil analisis statistik deskriptif diperoleh rerata $(\mathrm{M})=7,44$; Simpangan Baku $(\mathrm{SB})=2,08$; Median $(\mathrm{Me})=7,00$; dan Modus $(\mathrm{Mo})=6,00$. 
Berdasarkan hasil analisis deskriptif tersebut diketahui nilai rerata 7,00 dan nilai standar deviasi sebesar 2,08 yang selanjutnya digunakan sebagai dasar penyusunan norma dan standar core test.

$\begin{array}{llr}\text { Mean } & = & 7.44 \\ \text { St. Dev } & = & 2.08 \\ \mathrm{Mi}+1.5 \mathrm{SDi} & = & 10.56 \\ \mathrm{Mi} & = & 7.44 \\ \mathrm{Mi}-1.5 \mathrm{SDi} & = & 4.32\end{array}$

Selanjutnya dimasukkan dalam formulasi rumus berikut.

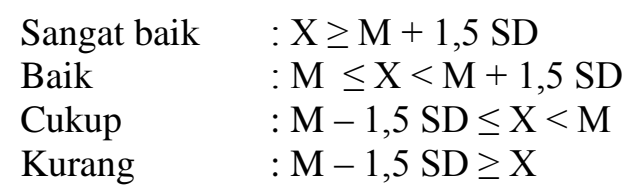

Diperoleh hasil perhitungan norma dan standar tes keterampilan fisik bolabasket pada daya tahan kekuatan menggunakan core test sebagai berikut.

\begin{tabular}{|c|c|c|c|c|c|}
\hline Kategori & \multicolumn{5}{|c|}{ Skor } \\
\hline Sangat baik & $X$ & $\geq$ & 10.56 & & \\
\hline Baik & $: 7.44$ & $\leq$ & $X$ & $<$ & 10.56 \\
\hline Cukup & $: \quad 4.32$ & $\leq$ & $\mathrm{X}$ & $<$ & 7.44 \\
\hline Kurang & $X$ & $\leq$ & 4.32 & & \\
\hline
\end{tabular}

Maka norma dan standar penilaian daya tahan kekuatan menggunakan core test pada tes keterampilan fisik bolabasket tingkat SMA adalah sebagai berikut.

Tabel 15. Norma dan Standar Penilaian Daya Tahan Kekuatan Menggunakan Core Test pada

Tes Keterampilan Fisik Bolabasket Tingkat SMA

\begin{tabular}{cc}
\hline Interval Skor & Kategori \\
\hline$x \geq 10,56$ & Sangat baik \\
$7,44 \leq$ s.d $<10,56$ & Baik \\
$4,32 \leq$ s.d $<7,44$ & Cukup \\
$x<4,32$ & Kurang \\
\hline
\end{tabular}

Tes Daya Tahan Aerobik (Bleep Test)

Hasil pengujian analisis deskriptif hasil tes daya tahan aerobik menggunakan bleep test adalah sebagai berikut.

Tabel 16. Hasil Analisis Deskriptif Data Daya Tahan Aerobik (Bleet Test)

\begin{tabular}{|c|c|c|c|c|c|}
\hline \multicolumn{6}{|c|}{ Data Bleep test } \\
\hline Min & Max & Mean & Median & Modus & Std. De \\
\hline 35,70 & 55,80 & 45,39 & 45,80 & 45,80 & 4,05 \\
\hline
\end{tabular}
skor terendah adalah 35,70 dan skor tertinggi adalah 55,80. Hasil analisis statistik deskriptif diperoleh rerata $(M)=45,39$; Simpangan Baku
$(\mathrm{SB})=4,05 ;$ Median $(\mathrm{Me})=45,80 ;$ dan Modus $(\mathrm{Mo})=45,80$.

Berdasarkan hasil analisis deskriptif tersebut diketahui nilai rerata 45,39 dan nilai standar deviasi sebesar 4,05 yang selanjutnya digunakan sebagai dasar penyusunan norma dan standar bleep test. Perhitungan norma bleep test adalah sebagai berikut.

$\begin{array}{lr}\text { Mean } & 45.39 \\ \text { St. Dev } & 4.05 \\ \mathrm{Mi}+1.5 \mathrm{SDi} & 51.47 \\ \mathrm{Mi} & 45.39 \\ \mathrm{Mi}-1.5 \mathrm{SDi} & 39.32\end{array}$

Selanjutnya dimasukkan dalam formulasi rumus berikut.

$\begin{array}{ll}\text { Sangat baik } & : X \geq M+1,5 S D \\ \text { Baik } & : M \leq X<M+1,5 S D \\ \text { Cukup } & : M-1,5 S D \leq X<M \\ \text { Kurang } & : M-1,5 S D \geq X\end{array}$

Diperoleh hasil perhitungan norma dan standar tes keterampilan fisik bolabasket pada tes daya tahan aerobik menggunakan bleep test sebagai berikut.

\begin{tabular}{llrl}
\multicolumn{1}{c}{ Kategori } & & \multicolumn{3}{c}{ Skor } \\
Sangat baik & $:$ & $X$ & $\geq 51.47$ \\
Baik & $:$ & 45.39 & $\leq \mathrm{X}<51.47$ \\
Cukup & $:$ & 39.32 & $\leq \mathrm{X}<45.39$ \\
Kurang & $:$ & $\mathrm{X}$ & $\leq 39.32$
\end{tabular}

Maka norma dan standar penilaian daya tahan aerobik menggunakan bleep test pada tes keterampilan fisik bolabasket tingkat SMA adalah sebagai berikut.

Tabel 17. Norma dan Standar Penilaian Daya Tahan Aerobik Menggunakan Bleep Test pada Tes Keterampilan Fisik Bolabasket Tingkat SMA

\begin{tabular}{cc}
\hline Interval Skor & Kategori \\
\hline$x \geq 51,47$ & Sangat baik \\
\hline $45,39 \leq \mathrm{s} . \mathrm{d}<51,47$ & Baik \\
\hline $39,32 \leq \mathrm{s.d}<45,39$ & Cukup \\
\hline$x<39,32$ & Kurang \\
\hline
\end{tabular}

Setelah dihitung norma dan standar tes keterampilan fisik pada masing-masing komponen, selanjutnya diperhitungkan norma keterampilan fisik bolabasket secara keseluruhan. Perhitungan dilakukan dengan menggabungkan seluruh hasil pengukuran keterampilan fisik meliputi kecepatan, kelincahan, fleksibilitas, power lengan, power tungkai, daya tahan kekuatan, dan daya tahan aerobik menggunakan tes yang telah ditentukan. Oleh karena data diukur menggunakan battery test, maka data 
harus diubah dalam bentuk $\mathrm{Z}$ score dengan rumus sebagai berikut.

$$
\begin{array}{ll}
\text { Z Score } & =\frac{x-\bar{x}}{S t \cdot d e v} \\
x & : \text { Skor } \\
\bar{x} & : \text { Rerata } \\
\text { St. Dev } & : \text { Standar deviasi }
\end{array}
$$

Selanjutnya untuk menyamakan satuan, maka data harus diubah dalam bentuk $\mathrm{T}$ score dengan rumus sebagai berikut.

$$
\begin{array}{ll}
\text { T Score }= & 50+10 *\left(\frac{x-\bar{x}}{S D}\right) \\
x & : \text { Skor } \\
\bar{x} & : \text { Rerata } \\
\text { St. Dev } & : \text { Standar deviasi }
\end{array}
$$

Nilai $\mathrm{T}$ score pada masing-masing komponen tes keterampilan fisik selanjutnya dijumlahkan sehingga diperoleh skor keterampilan fisik secara keseluruhan. Total $t$-score tersebut selanjutnya digunakan untuk menghitung norma dan standard keterampilan fisik bolabasket secara keseluruhan. Hasil perhitungan normanya adalah sebagi berikut.

Tabel 18. Hasil Analisis Deskriptif Data

Keterampilan Fisik Bolabasket Secara

Keseluruhan

\begin{tabular}{cccccc}
\hline \multicolumn{5}{c}{ Data keterampilan fisik bolabasket } \\
\hline Min & Max & Mean & Median & Modus & Std. Dev \\
\hline 329,80 & 474,35 & 400,00 & 401,53 & 329,80 & 30,58 \\
\hline
\end{tabular}

Hasil analisis data keterampilan fisik keseluruhan diperoleh skor terendah adalah 329,80 dan skor tertinggi adalah 474,35. Hasil analisis statistik deskriptif diperoleh rerata (M) $=400,00$; Simpangan Baku $(\mathrm{SB})=30,58$; Me$\operatorname{dian}(\mathrm{Me})=401,53$; dan Modus $(\mathrm{Mo})=329,80$.

Berdasarkan hasil analisis deskriptif tersebut diketahui nilai rerata 400,00 dan nilai standar deviasi sebesar 30,58 yang selanjutnya digunakan sebagai dasar penyusunan norma dan standar keterampilan fisik bolabasket. Perhitungan norma keterampilan fisik bolabasket adalah sebagai berikut.

\begin{tabular}{|c|c|c|c|c|c|}
\hline Kategori & & & Skor & & \\
\hline Sangat baik & $X$ & $\geq$ & 445.87 & & \\
\hline Baik & 400.00 & $\leq$ & $X$ & $<$ & 445. \\
\hline Cukup & 354.13 & $\leq$ & $\mathrm{X}$ & $<$ & 400. \\
\hline Kurang & $X$ & $\leq$ & 354.13 & & \\
\hline
\end{tabular}

$\begin{array}{llr}\text { Mean } & =400.00 \\ \text { St. Dev } & =30.58 \\ \mathrm{Mi}+1.5 \mathrm{SDi} & =445.87 \\ \mathrm{Mi} & =400.00 \\ \mathrm{Mi}-1.5 \mathrm{SDi} & = & 354.13\end{array}$

Selanjutnya dimasukkan dalam formulasi rumus berikut.

$\begin{array}{ll}\text { Sangat baik } & : X \geq M+1,5 S D \\ \text { Baik } & : M \leq X<M+1,5 S D \\ \text { Cukup } & : M-1,5 S D \leq X<M \\ \text { Kurang } & : M-1,5 S D \geq X\end{array}$

Diperoleh hasil perhitungan norma dan standar tes keterampilan fisik bolabasket sebagai berikut.

Norma dan standar penilaian eterampilan fisik bolabasket tingkat SMA adalah sebagai berikut.

\begin{tabular}{|c|c|c|c|c|c|c|c|}
\hline No & Nama & Speed (detik) & T Score & $\begin{array}{l}\text { bleep test } \\
\mathrm{ml} / \mathrm{kg} / \mathrm{min}\end{array}$ & T Score & $\begin{array}{c}\text { agility test } \\
\text { (detik) }\end{array}$ & T Score \\
\hline 1 & Agyl & 3.15 & 35.15 & 45.2 & 49.52 & 12.8 & 61.59 \\
\hline & $\frac{\text { core test }}{\text { (level })}$ & T Score & $\frac{\text { Vertical jump }}{(\mathrm{cm})}$ & T Score & Push-up & T Score & \\
\hline & 8 & 52.68 & 48 & 43.03 & 26 & 52.28 & \\
\hline & Sit and react & & & ourt sht & k) & T Score & Total \\
\hline & 13.4 & & & 28.07 & & 49.50 & 383.61 \\
\hline
\end{tabular}

Tabel 19. Norma dan Standar Penilaian Tes Keterampilan Fisik Bolabasket Tingkat SMA

\begin{tabular}{ccrr}
\hline Interval Skor & & \multicolumn{1}{c}{ Kategori } \\
\hline$x$ & $\geq 445,87$ & & Sangat baik \\
400,00 & $\leq \mathrm{s} . \mathrm{d}<445,87$ & & Baik \\
354,13 & $\leq \mathrm{s} . \mathrm{d}<400,00$ & & Cukup \\
$x$ & $<354,13$ & & Kurang \\
\hline
\end{tabular}

Norma tersebut digunakan untuk mengetahui keterampilan fisik bolabasket secara keseluruhan. Contoh perhitungannya adalah sebagai berikut. 
Berdasarkan data contoh di atas diketahui total T score yang diperoleh Agyl adalah sebesar 383,61 . Berdasarkan norma dan standar tes keterampilan fisik menunjukkan Agyl mempunyai keterampilan fisik bolabasket kategori cukup.

\section{Norma dan Standar Modifikasi Tes Keterampilan Fisik Bolabasket}

Hasil dari masing-masing jenis tes kemudian disimpulkan menjadi satu tabel untuk mempermudah dalam mengevaluasi. Berikut norma dan standar modifikasi tes keterampilan fisik untuk cabang olahraga bolabasket.

Tabel 20. Norma dan Standar Modifikasi Tes

Keterampilan Fisik Cabang Olahraga Bolabasket

\begin{tabular}{|c|c|}
\hline \multicolumn{2}{|c|}{ Kecepatan } \\
\hline Interval Skor & Kategori \\
\hline$x \geq 4,58$ & Kurang \\
\hline $3,86 \leq \mathrm{s} . \mathrm{d}<4,58$ & Cukup \\
\hline $3,14 \leq \mathrm{s} . \mathrm{d}<3,86$ & Baik \\
\hline$x<3,14$ & Sangat Baik \\
\hline \multicolumn{2}{|c|}{ Kelincahan } \\
\hline Interval Skor & Kategori \\
\hline$x \geq 14,86$ & Kurang \\
\hline $13,69 \leq \mathrm{s} . \mathrm{d}<14,86$ & Cukup \\
\hline $12,52 \leq \mathrm{s} . \mathrm{d}<13,69$ & Baik \\
\hline$x<12,52$ & Sangat baik \\
\hline \multicolumn{2}{|c|}{ Fleksibilitas } \\
\hline Interval Skor & Kategori \\
\hline$x \geq 25.75$ & Sangat baik \\
\hline $18.37 \leq \mathrm{s} . \mathrm{d}<25.72$ & Baik \\
\hline $11.02 \leq \mathrm{s} . \mathrm{d}<18.37$ & Cukup \\
\hline$x<11.02$ & Kurang \\
\hline \multicolumn{2}{|c|}{ Power lengan } \\
\hline Interval Skor & Kategori \\
\hline$x \geq 31,08$ & Sangat baik \\
\hline $25,09 \leq \mathrm{s} . \mathrm{d}<31,08$ & Baik \\
\hline $19,11 \leq$ s.d $<25,09$ & Cukup \\
\hline$x<19,11$ & Kurang \\
\hline \multicolumn{2}{|c|}{ Power tungkai } \\
\hline Interval Skor & Kategori \\
\hline$x \geq 66,20$ & Sangat baik \\
\hline $53,78 \leq$ s.d $<66,20$ & Baik \\
\hline $41,36 \leq \mathrm{s} . \mathrm{d}<53,78$ & Cukup \\
\hline$x<41,36$ & Kurang \\
\hline \multicolumn{2}{|c|}{ Daya tahan kekuatan } \\
\hline Interval Skor & Kategori \\
\hline$x \geq 10,56$ & Sangat baik \\
\hline $7,44 \leq \mathrm{s} . \mathrm{d}<10,56$ & Baik \\
\hline $4,32 \leq \mathrm{s} . \mathrm{d}<7,44$ & Cukup \\
\hline$x<4,32$ & Kurang \\
\hline
\end{tabular}

\begin{tabular}{|c|c|}
\hline \multicolumn{2}{|c|}{ Daya tahan aerobik } \\
\hline Interval Skor & Kategori \\
\hline$x \geq 51,47$ & Sangat baik \\
\hline $45,39 \leq \mathrm{s} . \mathrm{d}<51,47$ & Baik \\
\hline $39,32 \leq \mathrm{s} . \mathrm{d}<45,39$ & Cukup \\
\hline$x<39,32$ & Kurang \\
\hline \multicolumn{2}{|c|}{ Keterampilan Fisik Bolabasket Keseluruhan } \\
\hline Interval Skor & Kategori \\
\hline$x \geq 445,87$ & Sangat baik \\
\hline $400,00 \leq \mathrm{s} . \mathrm{d}<445,87$ & Baik \\
\hline $354,13 \leq \mathrm{s} . \mathrm{d}<400,00$ & Cukup \\
\hline$x<354,13$ & Kurang \\
\hline
\end{tabular}

\section{SIMPULAN DAN SARAN}

\section{Simpulan}

Sebagaimana tujuan penelitian yaitu mengembangkan tes kemampuan fisik bolabasket bagi siswa SMA putra, maka dilakukan penelitian pengembangan dengan sepuluh (10) langkah, terdiri atas: (1) review kriteria tes keterampilan fisik bolabasket, (2) melakukan analisis terhadap informasi yang dikumpulkan, (3) melakukan kajian literatur, (4) memilih jenis tes, (5) mengembangkan prosedur pelaksanaan tes, (6) peer review atau validasi ahli, (7) penyusunan produk awal, (8) uji validitas dan reliabilitas skala kecil, (9) pengujian skala besar untuk membuat norma dan standar penilaian, (10) pembuatan produk final.

Produk penelitian berupa buku yang disertai dengan petunjuk penggunaan tes, pengukuran dan evaluasi. Di dalam buku yang berjudul basketball physical test on high school berisi penjelasan mulai dari persiapan untuk melaksanakan tes sampai dengan cara mengevaluasinya. Istrumen untuk bleep test dilampirkan dalam tampilan format mp3 sehingga lebih mudah dalam pengoperasiannya.

Hasil penilaian para ahli materi terhadap pengembangan tes kemampuan fisik bolabasket bagi siswa SMA putra, disimpulkan bahwa tes disusun dengan sangat baik dan efektif. Produk pengembangan tes layak digunakan untuk mengukur dan mengevaluasi kemampuan fisik bagi siswa SMA putra.

\section{Saran}

Saran Pemanfaatan berdasarkan penelitian pengembangan yaitu agar tes kemampuan fisik yang telah dikembangkan ini dapat digunakan guru maupun pelatih sebagai sport skills test khususnya cabang olahraga bolabasket siswa SMA sehingga dapat diketahui kemampuan 


\section{Jurnal Keolahragaan 4 (1), April 2016 - 97}

Taufiq Arif Setyawan, F.X. Sugiyanto

siswa yang sebenarnya sebagai dasar untuk pengambilan keputusan strategis.

Diseminasi hasil penelitian ini dapat dilakukan melalui seminar-seminar, publikasi melalui artikel, buku, dan website sehingga dapat dijadikan informasi ilmiah. Manfaat yang paling penting bahwa hasil penelitian ini dapat dimanfaatkan sebagai dasar pengambilan keputusan dalam cabang olahraga bolabasket pada kelompok umur siswa SMA.

Pengembangan produk lebih lanjut perlu dilakukan penelitian yang melibatkan subjek coba yang lebih besar dan cakupan tempat uji coba yang lebih luas. Di sisi lain, dapat juga dilakukan penelitian serupa pada sasaran subjek kelompok umur dan tingkatan siswa atau atlet yang berbeda.

\section{DAFTAR PUSTAKA}

Azwar. S. (2007). Reliabilitas dan validitas. Yogyakarta: Pustaka Pelajar.

Bompa, T.O. (1999). Theory and methodology of training. the key to athletic performance, $\left(4^{\text {th }} e d\right.$.). Dubuque, Iowa: Kendall/ Hunt Publishing Company.

Budiwanto, S. (2003). Prosedur menyusun tes keterampilan olahraga. Jurnal IPTEK Olahraga, Volume 5 Nomor 2 Mei 2003, 133-150.
Hoy, L \& Carter, C.A. (2007). Tackle basketball. New South Wales: Stanley Paul \& Co. Ltd.

Morrow, J.R. Jr; Jackson, A.W; Disch, J.G; \& Mood, D.P. (2005). Measurement and evaluation in human performance, $\left(3^{\text {rd }}\right.$ ed.). Colorado: Human Kinetics.

Ngatman. (2003). Tes dan pengukuran dalam pendidikan jasmani, Olahraga Majalah Ilmiah, Volume 9 Agustus 2003, 46-63.

Sugiyono. (2011) Metode penelitian pendidikan pendekatan kuantitatif, kualitatif, dan $R \&$ $D$. Bandung: Alfabeta.

Syafii, I. (2007). Pengembangan rangkaian tes keterampilan teknik dasar sepakbola pemain usia dini, Ringkasan Disertasi. Surabaya: PPS UNESA.

Trninic, S. (2003). The intregated in-season training of basketball cadets, Fiba assist magazine, tersedia di www.Fibaassist.com diambil tanggal 1 Agustus 2011.

Zhannisa, U., \& Sugiyanto, F. (2015). Model tes fisik pencarian bakat olahraga bulutangkis usia di bawah 11 tahun di DIY. Jurnal Keolahragaan, 3(1), 117 126. 